\title{
Synthesis and Characterization of the System (EP-n-MgO) Used in Thermal Ablation Applications
}

\author{
Jafer Fahdel Odah, Fadhil K. Farhan, and Ahmed Abed Anber \\ Al-Karkh University of Science, \\ College of Science, Department of Medical Physics, \\ Haifa St. Hamada Palace, \\ Al-Karkh Side, Baghdad, Iraq
}

In the current research, magnesium oxide nanopowder $(n-\mathrm{MgO})$ was prepared using dry chemistry method. The structural characterization of the prepared $n$-MgO was carried out using $\mathrm{x}$-ray diffraction (XRD) technique and scanning electron microscope (SEM). The powder was mixed with epoxy resin at ratios of $2 \%, 4 \%, 6 \%$ and $8 \%$. The effect of reinforcement of $n$-MgO on thermal properties of epoxy-resin-based composites such as thermal rate and insulation index was studied at three different temperatures: 380,680 and $>1800$ $\mathrm{K}$. Thermal testing that was carried out included thermal conductivity measurement using Mathis TCi and erosion rate test using oxy-acetylene flame technique. The results showed that increasing the content of $n$-MgO can significantly enhance the thermal properties such thermal conductivity, thermal diffusion, specific heat capacity as well as thermal resistance.

У поточному дослідженні нанопорошковий оксид магнію ( $n$ - $\mathrm{MgO}$ ) було приготовано методою «сухої» хімії. Структурна характеризація підготовленого $n-\mathrm{MgO}$ проводилася з використанням рентгенівської дифракційної (XRD) техніки та сканувального електронного мікроскопа (SEM). Порошок змішували з епоксидною смолою у співвідношенні $2 \%, 4 \%, 6 \%$ і $8 \%$. Вплив армування $n$ - $\mathrm{MgO}$ на теплові властивості композитів на основі епоксидної смоли, такі як теплова швидкість і індекс ізоляції, вивчався за трьох різних температур: 380,680 і > 1800 К. Теплові випробування, які проводилися, включали міряння теплопровідности з використанням Mathis TCi i випробування швидкости ерозії з використанням техніки киснеацетиленового полум'я. Результати показали, що збільшення вмісту $n$-MgO уможливлює значно підвищити теплові властивості, такі як теплопровідність, термічна дифузія, питома тепломісткість, а також термостійкість.

Key words: epoxy resin, magnesium oxide, thermal ablation, thermal characterization. 
Ключові слова: епоксидна смола, оксид магнію, термічна абляція, термічна характеризація.

(Received 30 December, 2019)

\section{INTRODUCTION}

Due to their low thermal conductivity and wholly high thermal steadiness, polymer composites are broadly utilized for high temperature thermal sheltering in several fields. Epoxy resins are important due to applications in many fields such as coating, electrical devices, electronics, dipping compounds, moulding powders and reinforced plastic industries [1].

Ablation enables us to understand the procedure of heat and mass transfer [2]. Ablation phenomena can be clarified using ablation mechanism; when a thermal flux is applied to the surface of a composite material, it first works as a heat sink: as heating ascertainment, the polymer outer layer become viscous and then starts to degenerate and then producing a foaming char. The char is a thermal insulator; its internal layer is cooled by volatile material percolating through from the degraded polymer [3].

The presence of thermal properties for composite materials is important. It signifies the reliance of the material expansion on a particular swing of temperature and how much the material temperature ascents due to the input heat over and above to material heat conductance [4].

Materials that are made from composite of different types of materials can be used instead of the natural materials. Such as steel, which is not good in the corrosion and the wood over time, strength would be reduced. Composite materials include a matrix material hold the reinforcement together and the fibres act as reinforcement. The thermal conductivity lacks by increment these fillers with different particle size distributions. In this context, inorganic filler was added into an EP matrix to form effectual composites, which is a potential route to amend the fineness of the final product. There are many types of fillers with high thermal conductivity and low thermal expansion coefficient, such as silica [5], alumina [6], and aluminium nitride [7] were studied.

Some studies have elucidated the effect of different types of nanofillers sank in epoxy-based composites on the mechanical [8.], thermal [9] or electrical [10] properties.

Metal oxide nanoparticles preparation with the use of plant extract is a hopeful alternative to traditional chemical sorts. Magnesium oxide is a remarkable functional metal oxide that has been widely used in sundry domains, such as catalysis, pigmentation, and superconductors [11]. 
There are some samples of the synthesis of $n$-MgO using Clitoria ternatea, neem leaves [12], Parthenium [13], Brassica oleracea, Punica granatum peels [14], citrus lemon [15] or the extract drawn up from Nephelium lappaceum $L$ peels [16].

Experimental studies on the effect of $n$-MgO content synthesized using citrus senensis peels on epoxy resins were reported in detail in the current study.

\section{EXPERIMENTAL}

Magnesium oxide nanopowder ( $n$-MgO) was prepared using dry chemistry way, where citrus senensis peels (orange cortex) were used as a catalyst after the extraction of their solution (separated). This solution mixed with magnesium nitrate and ammonium hydroxide. A $30 \mathrm{ml}$ of citrus senensis peels separated was mixed with a $10 \mathrm{ml}$ of $\mathrm{Mg}\left(\mathrm{NO}_{3}\right)_{6} \mathrm{H}_{2} \mathrm{O}$ on the magnetic stirrer to obtain a homogeneous solution. To get a final gel at $\mathrm{pH}=7$, few drops of $\mathrm{NH}_{4} \mathrm{OH}$ were added stepby-step with continuous shaking at $90^{\circ} \mathrm{C}$ to $120^{\circ} \mathrm{C}$, here the gel turns to sol. Owing to the existence of citrus senensis peels, burning and glow may be eventuated intra flask.

After $n$-MgO synthesis, epoxy resin with a weight proportion $2 \%$, $4 \%, 6 \%$, and $8 \%$ was used to consolidate the nanopowder.

Solution-blending method and ultrasonic technique were used to prepare the final nanocomposites, where $n-\mathrm{MgO}$ was distributed within the resin homogeneously to pledge fully reinforcement and to obviate holes formation inside the prepared nanocomposites. Moulds were permeable according to the standard criteria of thermal flake with dimensions of $6 \times 6 \times 0.5 \mathrm{~cm}$, which was made from Teflon.

Final nanocomposites were casted in the moulds and left 24 hours in a dark place. Then, XRD and SEM investigations were performed.

Figure 1 shows the experimental set up designed locally, which consists of oxygen and carbon dioxide gases mixture in a cylinder. This cylinder is used to generate the oxyacetylene flame.

Each sample was placed at $2 \mathrm{~cm}$ from the flame nozzle and prime exemplifies to prevent any overthrow or movement resulted from flow of the flame. Temperature of flow reaches $1800^{\circ} \mathrm{C}$, which was measured using a thermometer connected to the sample. The flame is broken up when a hole eventuated on the sample with recording the time, which was later used to calculate the ablation rate $\left(E_{r}\right)$ according to the following equation [17]:

$$
E_{r}=\frac{d_{s}}{b_{s}},
$$

where $d_{\mathrm{s}}$ is the thickness of the sample and $b_{s}$ is the time intransitive to 


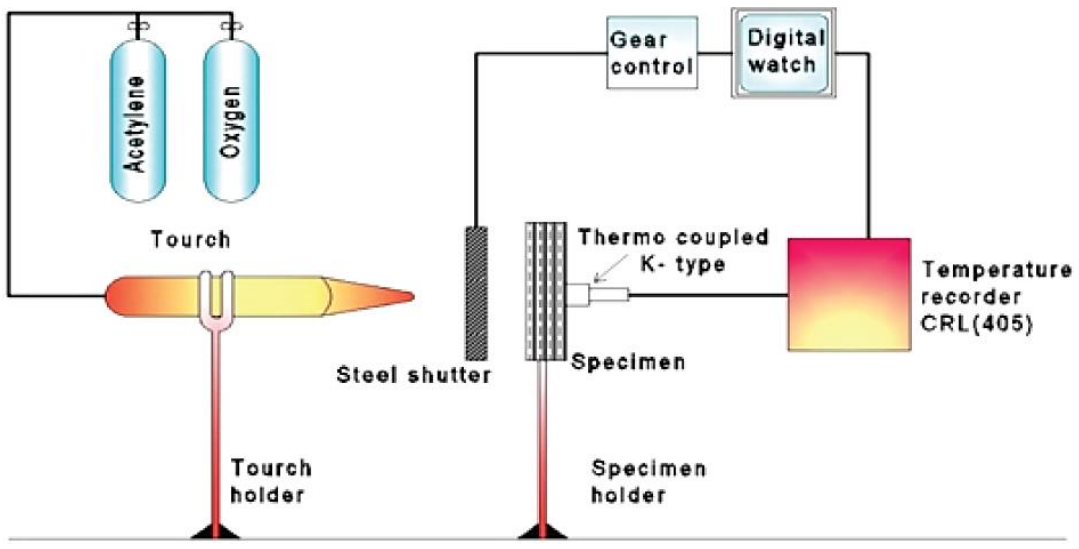

Fig. 1. Thermal ablative set up.

form a hole in the sample (burn through time).

Insulation rate $\left(I_{r}\right)$ also can be calculated using the equation [18]:

$$
I_{r}=\frac{1}{E_{r}} .
$$

Thermal diffusion ( $\delta_{\text {ther }}$ ) can be calculated after measuring the thermal conductivity $(\lambda)$ using the thermal conductivity analysis technique (Mathis TCi). The equations (3)-(6) were used to calculate the thermal flow $\left(\varepsilon_{\text {ther }}\right)$, thermal diffusion (thermal flux) and the thermal resistance $(R)[19]:$

$$
\begin{gathered}
\frac{d Q}{d t}=H=\lambda A \frac{d T}{d x}, \\
\varepsilon_{\text {ther. }}=\sqrt{\lambda C_{p} \rho}, \\
d_{\text {ther. }}=\frac{\lambda}{C_{p} r}, \\
R_{\text {ther. }}=\frac{d x}{\lambda},
\end{gathered}
$$

where $Q$ is the heat flow per time; $H$ is the heat; $t$ is the time; $T$ is the temperature; $x$ is the height of specimen; $A$ is the cross sectional area; $C_{p}$ is the specific heat capacity and $\rho$ is the density of the sample.

\section{RESULTS AND DISCUSSION}

X-ray diffraction (XRD) analysis of $\mathrm{MgO}$ sample was carried out on an 


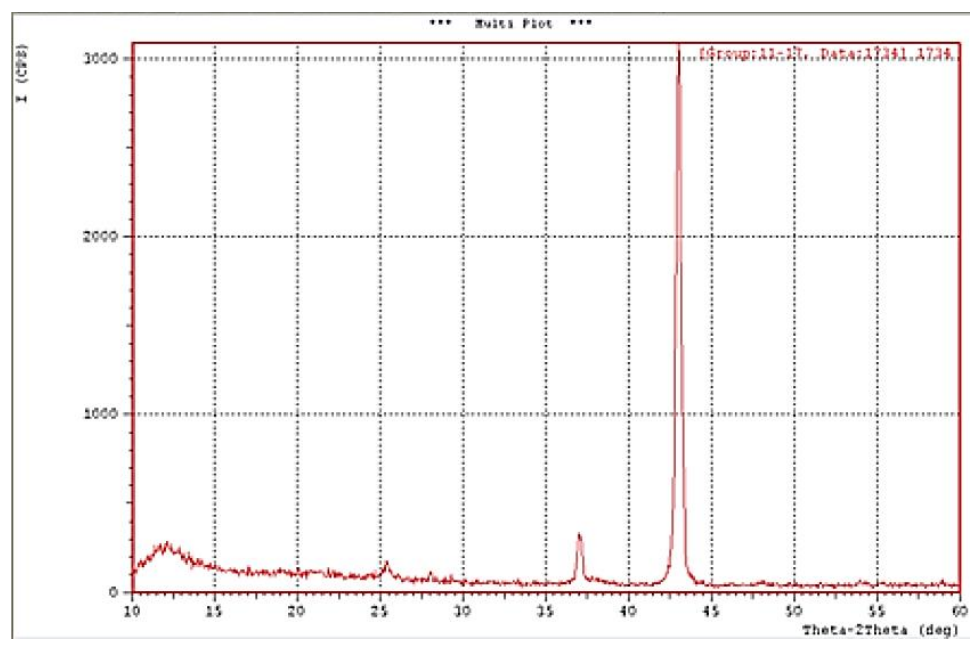

Fig. 2. XRD of MgO nanopowder.

x-ray diffractometer. Figure 2 shows the XRD pattern of the obtained $n$-MgO. The observed sharp suggests the presence of the crystalline phase with an f.c.c. structure.

The surface morphological features such as shape, particle size and composition of the $\mathrm{MgO}$ nanoparticles were measured using scanning electron spectroscope. From Fig. 3, it was noticed that the surface morphologies were in the form of agglomerates of nanoparticles as round shape. The $\mathrm{MgO}$ nanoparticles were allotment orderly over the interior surface. The SEM images of the obtained magnesium nanoparticles revealed that the prepared powders were consisted of a mixture of fine and large grains of the product particles.

Figure 4 shows the relationship between the ablation rates the ratio of $n-\mathrm{MgO}$ doping at three different temperatures range: 380,680 and $>1800 \mathrm{~K}$.

Reinforcing $n$-MgO may act as a heat dissipater or provide a much better network for transferring heat randomly. This may hand over the heat path onward from the targeted direction more than the pure resin would do. Hence, the $n-\mathrm{MgO}$ network will act as an additional heat barrier.

Figure 5 shows the insulation index of the system $\mathrm{EP}-n-\mathrm{MgO}$ as a function of $n-\mathrm{MgO}$ wt.\% at different three temperatures: 380, 680, $>1800 \mathrm{~K}$.

At temperatures of 380 and $680 \mathrm{~K}$, the interior of the final samples was cooled by a volatile material percolating through it from the decomposing polymer. During percolation, the volatiles are heated to high temperatures with decomposition to reduce the molecular weight species, which are pumped into the gases' boundary layer. This mass 


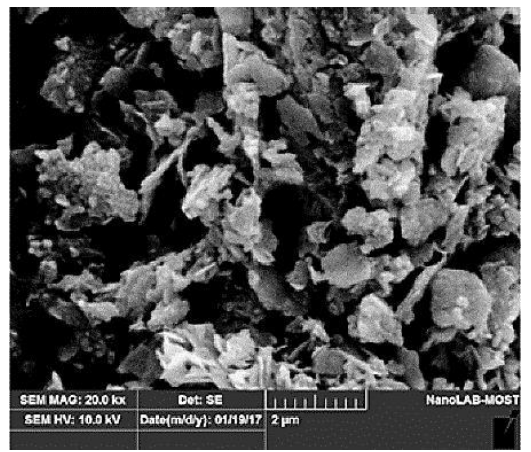

Fig. 3. SEM of MgO nanopowder.

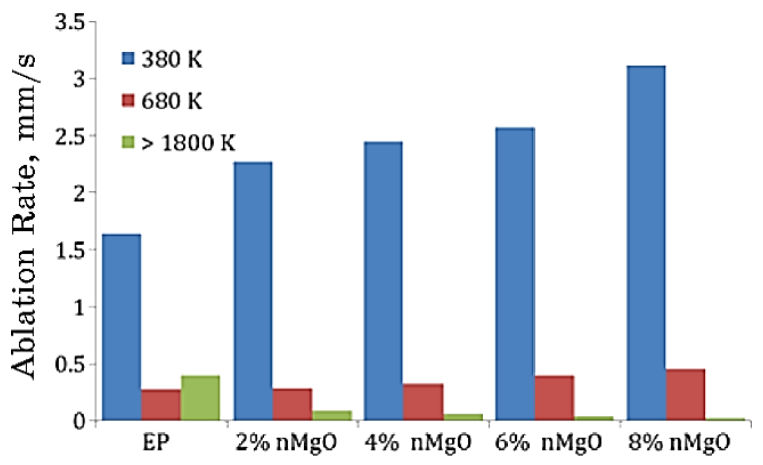

Fig. 4. Ablation rate as a function of $n$-MgO wt. $\%$ at temperatures $(380,680$, $>1800 \mathrm{~K})$.

pumping will create a blocking action, which reduces the heat transfer to the material. This process causes decrement in insulation index as the ratio of doping increasing. Thermal fragmentation of the polymer structure above $1800 \mathrm{~K}$, to yield lower molecular weight species, which evolve, with hydrogen gas, as the primary product. This leads to an increase the insulation index at this temperature.

Reinforcement by $n$-MgO leads to an increase in the thermal conductivity values with the increasing $n$ - MgO wt.\%. Figure 6 presents thermal conductivity of neat epoxy and epoxy composites with $n$-MgO content.

Thermal conductivity of the samples shows a significantly high increase with increasing $n$ - $\mathrm{MgO}$ content. Thermal conductivity of $\mathrm{EP}-n$ $\mathrm{MgO}$ system increases from $0.266 \mathrm{~W} /(\mathrm{m} \cdot \mathrm{K})$ for net epoxy to 0.845 $\mathrm{W} /(\mathrm{m} \cdot \mathrm{K})$ (3.17 folds enhancement) with the addition of $8 \mathrm{wt} \% \mathrm{n}$ $\mathrm{MgO}$. As the content of $n-\mathrm{MgO}$ is further increased to $8 \mathrm{wt} . \%$, the thermal diffusion is improved from $1.78 \mathrm{~mm}^{2} / \mathrm{s}$ to $5.41 \mathrm{~mm}^{2} / \mathrm{s}$. 


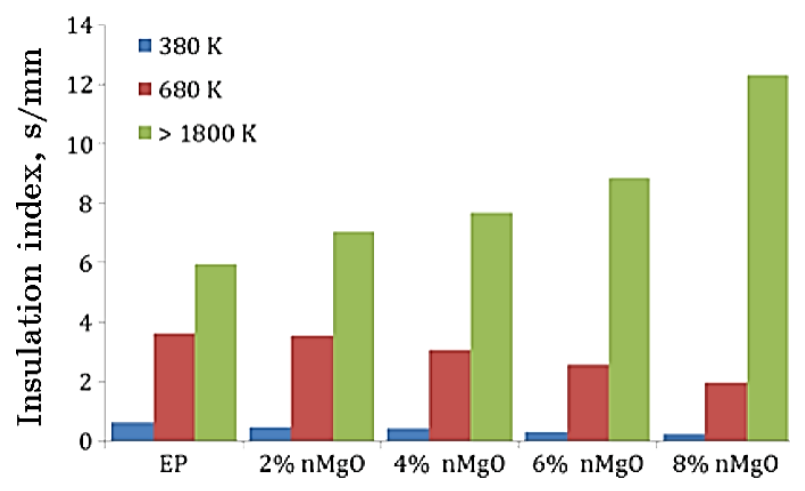

Fig. 5. Insulation index as a function of $n-\mathrm{MgO}$ wt. $\%$ at temperatures (380, $680,>1800 \mathrm{~K})$.

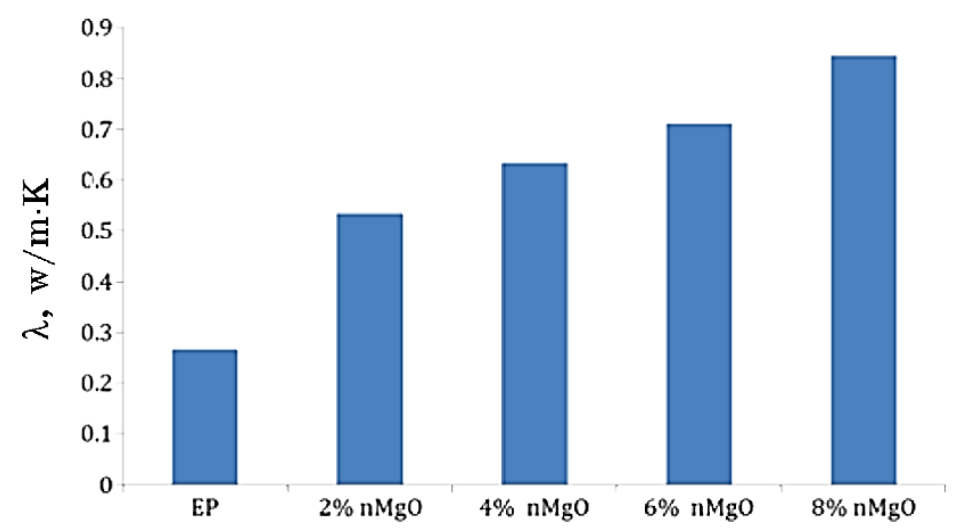

Fig. 6. Thermal conductivity as a function of $n-\mathrm{MgO}$ content.

For further realization of thermal conductive mechanism of epoxy composites relatively to phonon, it is deemed that phonon plays a significant function in heat conduction of majority polymer composites. Meanwhile, at high temperatures, the phonon-phonon interaction and the scattering of the phonon by the crystal borders determine the thermal conductivity of semiconductors [20]. Net epoxy has a scarce little heat conductivity due to the low crystallinity and phonon scattering of the randomly entangled molecule chains [21].

Density represents an important concept to explain the results obtained from the performance investigations for prepared composites, whereby the improvement of thermal conductivity can be improved based on the density of composites. Figure 7 clarifies that the density increases as reinforcing $n$-MgO wt.\% increases. This increase may be consoled to the chink of the holes formed, which resulted from the sur- 


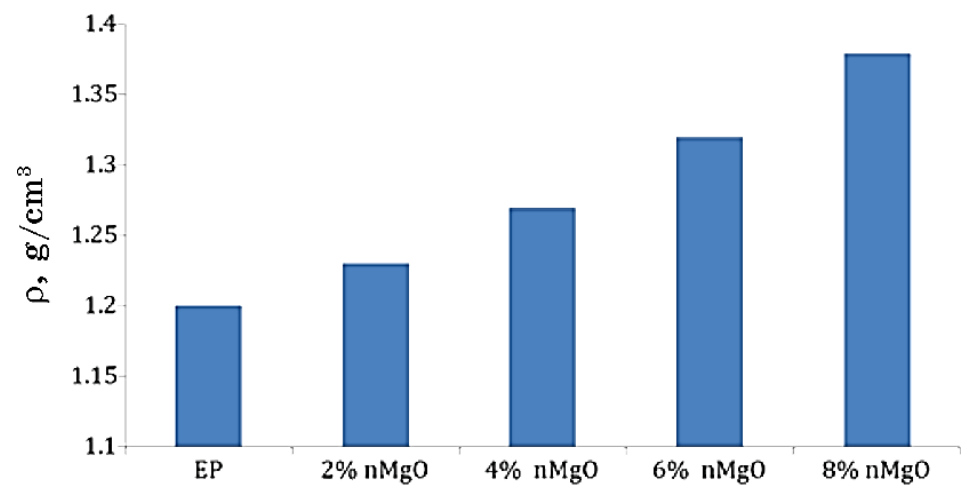

Fig. 7. Density as a function of $n-\mathrm{MgO}$ wt. $\%$.

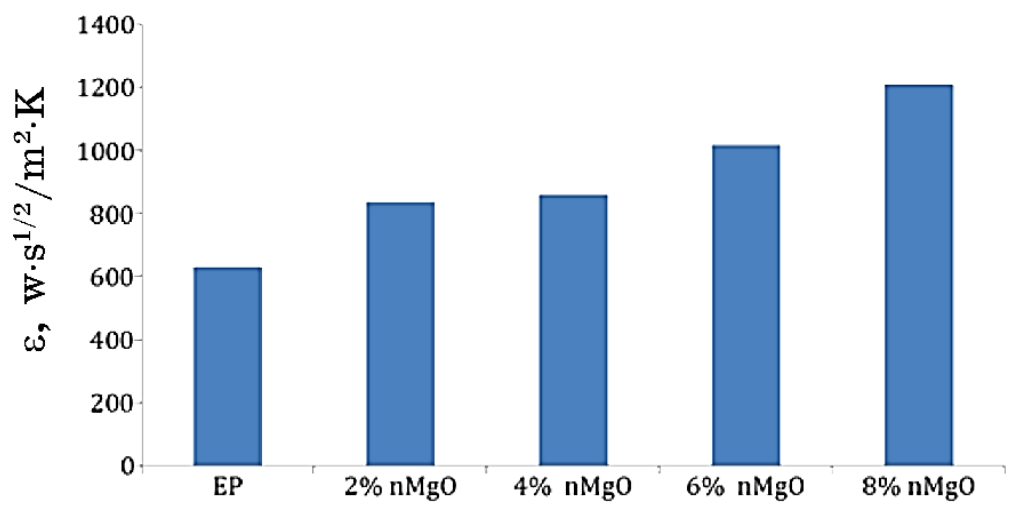

Fig. 8. Thermal flux as a function of $n-\mathrm{MgO}$ wt. $\%$.

rounding conditions during the preparation.

The density of $n-\mathrm{MgO}$ is doubled fold of the net epoxy and it is increasing as the ratio of $n-\mathrm{MgO}$ wt. $\%$ increases. This result agreed with previous work [23].

Thermal flux is one of the important parameters that can used to estimate the enhancement of thermal diffusion. Figure 8 presents the thermal flux as a function of $n-\mathrm{MgO}$ wt. $\%$.

Figure 8 shows that the thermal flux has improved with $n-\mathrm{MgO}$ wt. $\%$ increase. This enhances to the high thermal conductivity of reinforcing material ( $n-\mathrm{MgO})$, which reaches to $45-65 \mathrm{~W} /(\mathrm{kg} \cdot \mathrm{K})$.

Figure 9 shows the change of specific heat capacity of the neat epoxy resin in comparison system $\mathrm{EP}-n-\mathrm{MgO}$.

Figure 9 shows that the net epoxy has a specific heat of 1243.42 $\mathrm{J} /(\mathrm{kg} \cdot \mathrm{K})$, which is higher than that of the nanocomposites reinforced with different weight fractions of the $n$ - $\mathrm{MgO}$. The minimum value of specific heat were located for composite material reinforced with $8 \%$ 


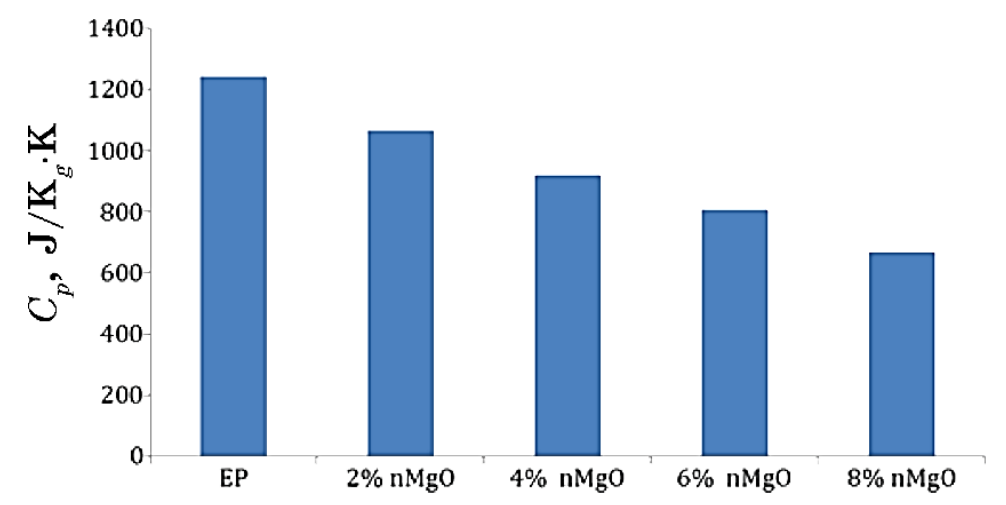

Fig. 9. Specific heat capacity as a function of $n-\mathrm{MgO}$ wt. $\%$.

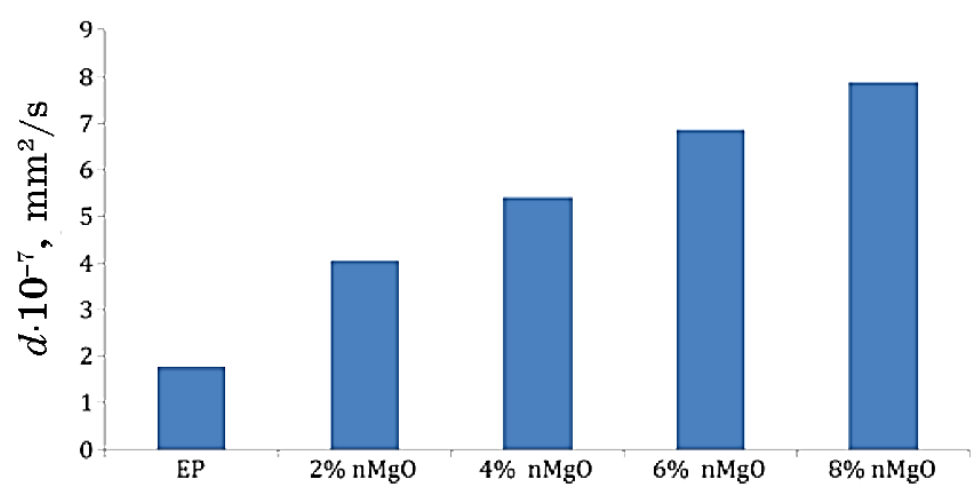

Fig. 10. Thermal diffusion as a function of $n-\mathrm{MgO}$ wt. $\%$.

weight fraction of $n-\mathrm{MgO}$ with values of $666.55 \mathrm{~J} /(\mathrm{kg} \cdot \mathrm{K})$. The reduction in heat capacity of the nanocomposite can be attributed to the low heat capacity of the used filler.

Figure 10 shows the thermal diffusion of epoxy reinforced with $n$ $\mathrm{MgO}$ wt. \% .

The thermal diffusion of the nanocomposite materials augments with the increase of the weight fraction of nanopowders. This can be explained from known that thermal diffusion is directly proportional to the thermal conductivity and inversely proportional to the specific heat of reinforcing materials as indicated in Eq. (5). These results agree with previous conclusions obtained in [22]. In addition, Figure 10 indicates that the thermal diffusion of the pure epoxy is $1.78 \cdot 10^{-7}$ $\mathrm{mm}^{2} / \mathrm{s}$. The value of thermal diffusion for the epoxy reinforced with $8 \%$ weight fraction of $n-\mathrm{MgO}$ powder equals to $7.87 \mathrm{~mm}^{2} / \mathrm{sec}$. This value was the highest compared with the epoxy alone and another EP$n$ - $\mathrm{MgO}$ mixture. 


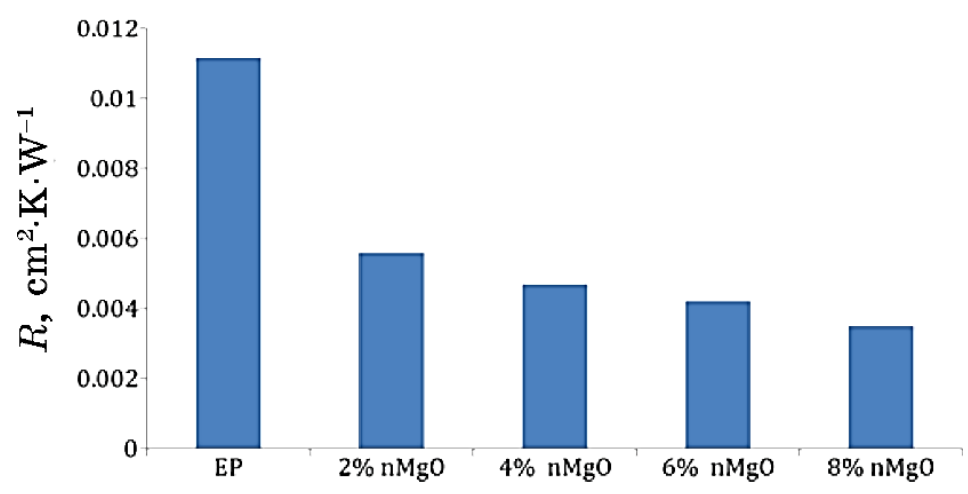

Fig. 11. Thermal resistance as a function of $n-\mathrm{MgO}$ wt. $\%$.

Thermal resistance measurement is a substantiation of prepared product qualification. At constant thickness, thermal resistance can be defined as the inverse of thermal conductivity. Figure 11 shows the acting of thermal resistance as a function of $n-\mathrm{MgO}$ wt. \% .

One can notice from Figure 11 that thermal resistance decreases as $n$ - $\mathrm{MgO}$ wt. $\%$ increase where $n$ - $\mathrm{MgO}$ dispersed the storage heat outgoing as thermal energy. The mechanism of thermal resistance is identical to that of electric oneself, whereas the excess of the electrons in $n$ $\mathrm{MgO}$ leads to an increase in thermal conductivity, which indicates a drop in the thermal resistance.

\section{CONCLUSIONS}

This study has demonstrated an approach to improve the thermal properties of epoxy composites filled by magnesium oxide nanocomposites. For instance, the thermal conductivity of epoxy composite with $8 \mathrm{wt} . \%$ of $n-\mathrm{MgO}$ was $0.845 \mathrm{~W} /(\mathrm{m} \cdot \mathrm{K})$ compared to that of the pure epoxy 0.266 $\mathrm{W} /(\mathrm{m} \cdot \mathrm{K})$. From the results of specific heat capacity and thermal diffusion, 0.8 wt. $\%$ of $n-\mathrm{MgO}$ is the best ratio to reinforce epoxy resin, which improved using this type of fillers.

\section{REFERENCES}

1. Epoxy Resin Chemistry and Technique (Eds. C. A. May and G. Y. Tanaka) (New York: Marcel Dekker: 1988).

2. Y. I. Dimitrienko, Int. J. Eng. Sci., 35: 15 (1997).

3. M. K. Seo, J. H. Byun, and S. J. Park, Studies on Morphologies and Mechanical Properties of Multi-Walled Carbon Nanotubes/Epoxy Matrix Composites (Incheon, Korea: Department of Chemistry, Inha University: 2010).

4. W. Bolton, Engineering Materials Technology (Heinemann: 1998). 
5. F. C. Ng, A. Abas, Z. L. Gan, M. Z. Abdullah, F. C. Ani, and M. Y. T. Ali, Microelectron. Reliab., 72: 45 (2017).

6. U. S. Jeong, Y. J. Lee, D. G. Shin, H. M. Lim, S. Y. Mun, W. T. Kwon, S. R. Kim, Y. H. Kim, K. B. Shim, Trans. Electr. Electron. Mater., 16: 351 (2015).

7. Y. C. Zhou, H. Wang, L. Wang, K. Yu, Z. D. Lin, L. He, and Y. Y. Bai, Mater. Sci.Eng. B, 177: 892 (2012).

8. M. I. Kim, S. Kim, T. Kim, D. K. Lee, B. Seo, and C.-S. Lim, Coatings, 7: 231 (2017).

9. X. Zhang, H. Wen, and Y. Wu, Polymers, 9: 430 (2017).

10. Я. Wang, J. Liu, Y. Cheng et al., Nanomaterials, 8: 242 (2018).

11. J. K. Salem, I. M. El-Nahhal, T. M. Hammad, and R. Hempelmann, Chem. Phys. Lett., 636: 26 (2015).

12. S. K. Moorthy, C. H. Ashok, K. Venkateswara Rao, and C. Viswanathan, Mater. Today Proc., 2: 4360 (2015).

13. D. Kumar, L. S. Reddy Yadav, K. Lingaraju et al., AIP Conf. Proc., 1665: 050145 (2015).

14. P. Sugirtha, R. Divya, R. Yedhukrishnan et al., Asian J. Chem., 27, No. 7: 2513 (2015).

15. A. V. Awwad and A. L. Ahmad, Arab. J. Phys. Chem., 1, No. 2: 66 (2014).

16. J. Suresh, R. Yuvakkumar, M. Sundrarajan, and S. I. Hong, Adv. Mater. Res., 952: 141 (2014).

17. Z. Eslami, F. Yazdani, and M. A. Mirzapour, Composites Part A: Applied Science and Manufacturing, 72: 22 (2015);

http://dx.doi.org/10.1016/j.compositesa.2015.01.015.

18. R. Srinivasan and V. Banton, App. Phys. Lett., 41: 576 (1982).

19. F. K. Farhan, B. J. Obeid, and M. O. Kadhim, Journ. of Adv. Research in Dynamical \& Control Systems, 10, Iss. 04 (2018).

20. H. Xu and D. Pasini, Sci. Rep., 6: 34924 (2016).

21. R. Agarwal, N. S. Saxena, K. B. Sharma, S. Thomas, and M. S. Sreekala, J.Appl. Polym. Sci., 89: 1708 (2003).

22. F. K. Farhan, Journal of Engineering, 24, No. 8: 1 (2018).

23. J. K. Oleiwi, S. I. Salih, and H. S. Fadhil, International Journal of Mechanical and Production, 8, Iss. 3: 1105 (2018). 